\title{
Intensity and timing of physical activity in relation to postmenopausal breast cancer risk: the prospective NIH-AARP Diet and Health Study
}

\author{
Tricia M Peters*1,2, Steven C Moore ${ }^{1}$, Gretchen L Gierach ${ }^{3,4}$, \\ Nicholas J Wareham² ${ }^{2}$ Ulf Ekelund ${ }^{2}$, Albert R Hollenbeck ${ }^{5}$, Arthur Schatzkin ${ }^{1}$ \\ and Michael F Leitzmann ${ }^{6}$
}

\begin{abstract}
Address: ${ }^{1}$ Nutritional Epidemiology Branch, Division of Cancer Epidemiology and Genetics, National Cancer Institute, NIH, DHHS, 6120 Executive Blvd, Bethesda, MD, USA, ${ }^{2}$ MRC Epidemiology Unit, Institute of Metabolic Science, Addenbrooke's Hospital, Hills Rd, Cambridge, UK, ${ }^{3}$ Hormonal and Reproductive Epidemiology Branch, Division of Cancer Epidemiology and Genetics, National Cancer Institute, NIH, DHHS, 6120 Executive Blvd, Bethesda, MD, USA, ${ }^{4}$ Cancer Prevention Fellowship Program, Office of Preventive Oncology, National Cancer Institute, NIH, DHHS, Bethesda, MD, USA, ${ }^{5}$ AARP, 601 E St NW, Washington, DC, USA and ${ }^{6}$ Department of Epidemiology and Preventive Medicine, University Medical Center Regensburg, Regensburg, Germany

Email: Tricia M Peters* - tricia.peters@mrc-epid.cam.ac.uk; Steven C Moore-moorest@mail.nih.gov;

Gretchen L Gierach - gierachg@mail.nih.gov; Nicholas J Wareham - nick.wareham@mrc-epid.cam.ac.uk; Ulf Ekelund - ulf.ekelund@mrcepid.cam.ac.uk; Albert R Hollenbeck - AHollenbeck@aarp.org; Arthur Schatzkin - schatzka@exchange.nih.gov;

Michael F Leitzmann - Michael.Leitzmann@klinik.uni-regensburg.de

* Corresponding author
\end{abstract}

Published: I October 2009

BMC Cancer 2009, 9:349 doi:10.1186/147I-2407-9-349
Received: 19 June 2009

Accepted: I October 2009

This article is available from: http://www.biomedcentral.com/I47I-2407/9/349

(C) 2009 Peters et al; licensee BioMed Central Ltd.

This is an Open Access article distributed under the terms of the Creative Commons Attribution License (http://creativecommons.org/licenses/by/2.0), which permits unrestricted use, distribution, and reproduction in any medium, provided the original work is properly cited.

\begin{abstract}
Background: Despite strong evidence of an inverse association of physical activity with postmenopausal breast cancer risk, whether a certain intensity or time of life of physical activity is most effective for lowering breast cancer risk is not known.

Methods: In 118,899 postmenopausal women in the prospective NIH-AARP Diet and Health Study, we examined the relations of light and moderate-to-vigorous intensity physical activity during four periods of life ("historical": ages 15-18, 19-29, 35-39 years; "recent": past 10 years) to postmenopausal breast cancer risk. Physical activity was assessed by self-report at baseline, and 4287 incident breast cancers were identified over 6.6 years of follow-up.

Results: In age-adjusted and multivariate Cox regression models, $>7$ hours/week of moderate-tovigorous activity during the past 10 years was associated with $16 \%$ reduced risk of postmenopausal breast cancer (RR:0.84; $95 \% \mathrm{Cl}: 0.76,0.93$ ) compared with inactivity. The association remained statistically significant after adjustment for BMI (RR:0.87; $95 \% \mathrm{Cl}: 0.78,0.96)$. Neither moderate-tovigorous activity during other periods of life nor light intensity activity during any period of life was related to breast cancer risk, and associations did not vary by tumor characteristics.
\end{abstract}

Conclusion: A high level of recent, but not historical, physical activity of moderate-to-vigorous intensity is associated with reduced postmenopausal breast cancer risk. More precise recall of recent physical activity than activity in the distant past is one possible explanation for our findings. 


\section{Background}

With an estimated 182,460 new cases diagnosed in the United States (U.S.) in 2008 [1], breast cancer is recognized as the most common cancer affecting U.S. women. Among the few modifiable risk factors for breast cancer, a high versus low level of physical activity has been consistently associated with $20-40 \%$ reduced risk of postmenopausal breast cancer [2-5]. In order to better characterize the physical activity-breast cancer relation, further investigation of specific parameters of physical activity such as the intensity and the time of life of physical activity that may be most effective for breast cancer prevention among postmenopausal women is needed $[3,5]$.

Some studies suggest that physical activity of vigorous intensity is associated with a greater reduction in breast cancer risk than low intensity activity [6-9], and a recent review [5] reported a more pronounced risk reduction for vigorous $(26 \%)$ than moderate $(22 \%)$ physical activity. Other investigations have not found a dose-response relation according to activity intensity levels [10-18].

In addition, two recent reviews [3,5] reported stronger inverse associations with breast cancer risk for adult activity than for activity during adolescence. However, supporting evidence from prospective studies among postmenopausal women is limited to a few studies $[12,19,20]$. Observation of a certain time period of life during which physical activity most strongly influences postmenopausal breast cancer risk would have substantial relevance for targeting age-specific interventions to increase activity.

Intensity- and/or age-dependent variation in the physical activity-breast cancer relation could also help inform the etiology of breast cancer. Several biological mechanisms by which physical activity is suggested to act on breast tumor development have been proposed [21,22], including lowering levels of endogenous sex hormones [23], modulating insulin and insulin-like growth factors, enhancing immunity, and reducing chronic inflammation [22], and it is possible that different intensities of physical activity during specific periods of life (eg: adolescence, premenopause, postmenopause) invoke distinct pathways to influence breast cancer risk.

We previously reported that women in the larger, baseline National Institutes of Health (NIH)-AARP (formerly the "American Association of Retired Persons") Diet and Health Study cohort who were physically active five or more times per week during the year prior to baseline questionnaire administration showed a 13\% reduced risk of postmenopausal breast cancer, with suggested heterogeneity in the association according to tumor estrogen receptor (ER) status and lifestyle and reproductive factors
[24]. In the present analysis, we followed up these results using detailed information on physical activity from the second stage of the prospective NIH-AARP study to evaluate the association of light and moderate-to-vigorous intensity physical activity during four periods of life from adolescence through adulthood with postmenopausal breast cancer risk overall and by ER status, tumor stage, and histology.

\section{Methods \\ Study population}

The NIH-AARP Diet and Health Study [25] was established in 1995-1996, when 3.5 million members of the AARP aged 50 to 71 years who resided in six U.S. states (California, Florida, Louisiana, New Jersey, North Carolina, and Pennsylvania) or two urban areas (Atlanta, Georgia, and Detroit, Michigan) were mailed a baseline questionnaire to assess diet, physical activity, and medical history. The present analysis is based on a detailed second questionnaire sent six months later to baseline questionnaire respondents, which was completed by 334,908 individuals.

After excluding men ( $\mathrm{n}=196,851)$, women with prevalent cancers (other than non-melanoma skin cancer) before baseline $(\mathrm{n}=8294)$, those missing all physical activity data from the second questionnaire $(n=1350)$, those with missing or extreme values of height or weight (the latter defined by the Box-Cox transformation [26], $n$ $=4055)$, those with no follow-up $(n=6)$ and women who were premenopausal $(n=4378)$ or whose menopausal status was unknown before baseline ( $\mathrm{n}=1075), 118,899$ women remained for the current analysis. The Special Studies Institutional Review Board of the National Cancer Institute approved this study, and completion of the selfadministered questionnaire was considered to imply informed consent.

\section{Cohort follow-up and case ascertainment}

Participants were followed for change of address by annual linkage to the U.S. Postal Service National Change of Address database, by notifications of undelivered mail, through other address update services, and by direct notice from participants. Vital status was ascertained by annual linkage to the Social Security Administration Death Master File, and searches of the National Death Index (NDI) Plus were used to verify vital status and to provide cause of death information.

Incident breast cancer cases were identified by linkage to eleven state cancer registries, with the addition of Texas, Arizona, and Nevada, to the eight states to which the questionnaires were originally posted. The estimated sensitivity of case ascertainment by cancer registry linkage was previously shown to be $90 \%$ [27]. 
ER status was available from seven (California, Louisiana, Georgia, North Carolina, New Jersey, Arizona, and Nevada) of the eleven reporting states, and tumors were classified as ER-positive at a threshold of at least 10 femtomoles of receptor per milligram total protein. Tumors classified as ER-unknown $(\mathrm{n}=1907)$ included borderline, missing, and unknown ER status.

Breast cancer cases were classified according to tumor histology by using the International Classification of Diseases for Oncology, $3^{\text {rd }}$ edition, coding system, with ductal tumors defined by codes 8500 or 8523 , lobular tumors by codes 8520 or 8524 , and tumors of mixed ductal-lobular histology by code 8522 .

\section{Physical activity assessment}

Physical activity was assessed in the second questionnaire by asking participants to report the duration per week (never, rarely, <1 hour per week, 1-3 hours per week, 4-7 hours per week, $>7$ hours per week) of light intensity activities given the examples "bowling, golf (riding in a cart), table tennis, slow walking/slow dancing, light calisthenics, light gardening, fishing, horseshoes/croquet, light housework," and of moderate-to-vigorous activities given the examples "tennis, golf (walking), biking, swimming, heavy gardening, weight lifting, basketball/baseball, football/soccer, cheerleading/drill team, handball/ racquetball, hiking/climbing mountains, fast walking/fast dancing, rowing, aerobics, jogging/running, heavy housework," during each of four separate life periods (age 15-18 years, 19-29 years, 35-39 years, and in the past 10 years). For each life period across both intensity levels, participants were classified into one of five physical activity categories, with the "never" and "rarely" questionnaire responders collapsed into one "inactive" category. Our physical activity instrument was developed with reference to the Physical Activity Scale for the Elderly (PASE) questionnaire, which has been validated using doubly labeled water $(r=0.58)[28]$ and has shown high reliability across administrations 3-7 weeks apart (ICC =0.84) [29].

\section{Statistical analysis}

Cox proportional hazards regression with age as the time metric was used to estimate the relative risk (RR) of breast cancer. Follow-up time was calculated from the scan date of the second questionnaire through the date of diagnosis of breast cancer, death, or the end of the study on December 31, 2003. Models were adjusted for potential confounding variables (Tables 1 \&2), and separate analyses were performed with the addition of baseline body mass index (BMI) or BMI at age 18 years and with exclusion of age at menarche as a covariate, since these factors could mediate the relation of physical activity to breast cancer. In secondary analyses, moderate-to-vigorous physical activity was added as a covariate in multivariate models for light physical activity during each period of life, and vice versa. We also assessed potential confounding by history of benign breast disease and by history of mammography in the past three years.

Stratified analyses were conducted to explore variation in the physical activity-breast cancer association by previously reported effect modifiers including baseline BMI, BMI at age 18 years, family history of breast cancer in firstdegree female relatives, parity, and menopausal hormone therapy use, and the statistical significance of the interaction was assessed by likelihood ratio tests comparing models with and without interaction terms.

In separate analyses, we investigated the relation of physical activity with breast cancer endpoint subgroups defined by ER status (ER-negative, ER-positive, or ERunknown tumors), tumor stage (invasive or in situ breast cancer), and histological subtype (ductal, lobular, or mixed ductal-lobular histology). Analyses of ER status and tumor histology were restricted to invasive cancers. Heterogeneity by the above tumor characteristics was evaluated using Cochran's Q statistic comparing risk estimates for the highest versus lowest physical activity level, for each distinct endpoint [30].

Spearman rank correlation coefficients $(\rho)$ examined the inter-relationship of physical activity measures across categories of intensity and time of life.

Analyses were performed using SAS (version 9.1; SAS Institute, Inc., Cary, North Carolina), with all statistical tests two-sided and conducted at the 0.05 significance level.

\section{Results}

Women were, on average, 62.9 years old at baseline, and most women were Caucasian (91.2\%) and 31.5\% were college-educated (Tables 1 \&2). Nearly fifty percent of participants reported engaging in more than three hours of moderate-to-vigorous physical activity during an average week in the past ten years (Table 2). Light intensity activities were more prevalent than moderate-to-vigorous activities across the lifespan, and women reported spending more time in moderate-to-vigorous activities during the younger life periods than during the past ten years.

Women who reported a high level of light or moderate-tovigorous activity between ages $15-18$ years had a slightly higher baseline BMI than women who were inactive at ages 15-18 years, whereas women who reported being highly active from ages 35-39 years and during the 10 years prior to questionnaire administration tended to have a lower baseline BMI than their inactive counterparts. Regardless of intensity level and time of life of activ- 
Table I: Characteristics of the study population by light and moderate-to-vigorous intensity physical activity during two periods of life: I I8,899 postmenopausal women in the NIH-AARP Diet and Health Study

\begin{tabular}{|c|c|c|c|c|c|c|c|c|c|c|c|}
\hline \multirow[t]{2}{*}{ Light activity } & \multirow[t]{2}{*}{ Total } & \multicolumn{5}{|c|}{ Ages $15-18$ years } & \multicolumn{5}{|c|}{ Ages $19-29$ years } \\
\hline & & $\begin{array}{l}\text { Neverl } \\
\text { Rarely }\end{array}$ & $<$ l hr/wk & I-3 hrs/wk & 4-7 hrs/wk & $>7 \mathrm{hrs} / \mathrm{wk}$ & $\begin{array}{l}\text { Neverl } \\
\text { Rarely }\end{array}$ & $<$ l hr/wk & I-3 hrs/wk & 4-7 hrs/wk & $>7 \mathrm{hrs} / \mathrm{wk}$ \\
\hline Participants, No. (\%) & 118899 & $10439(9)$ & 9199 (8) & $26777(23)$ & $26390(22)$ & $43700(37)$ & $5998(5)$ & $6400(5)$ & $20987(18)$ & $27569(23)$ & $55442(47)$ \\
\hline Age at baseline (yrs) & 62.9 & 62.6 & 62.4 & 62.7 & 62.9 & 63.1 & 62.7 & 62.3 & 62.5 & 62.7 & 63.1 \\
\hline BMI, current* $\left(\mathrm{kg} / \mathrm{m}^{2}\right)$ & 26.7 & 26.4 & 26.3 & 26.5 & 26.7 & 27.0 & 26.5 & 26.5 & 26.6 & 26.7 & 26.8 \\
\hline BMl at age $18^{*}\left(\mathrm{~kg} / \mathrm{m}^{2}\right)$ & 20.9 & 21.0 & 21.0 & 20.9 & 20.9 & 20.7 & 21.0 & 21.1 & 21.0 & 20.9 & 20.8 \\
\hline Caucasian (\%) & 91.2 & 89.5 & 90.4 & 91.5 & 91.9 & 91.8 & 85.6 & 88.4 & 89.8 & 91.7 & 92.9 \\
\hline College education (\%) & 31.5 & 32.3 & 32.9 & 33.0 & 33.1 & 29.7 & 32.9 & 34.4 & 35.7 & 33.9 & 28.8 \\
\hline $\begin{array}{l}\text { Family history of breast } \\
\text { cancert (\%) }\end{array}$ & 13.7 & 12.8 & 13.3 & 13.7 & 13.8 & 13.8 & 13.5 & 12.8 & 13.6 & 13.5 & 13.8 \\
\hline Current smoker (\%) & 13.4 & 11.2 & 12.2 & 13.0 & 12.9 & 14.7 & 11.9 & 11.8 & 12.8 & 13.3 & 14.0 \\
\hline Ever MHT use $\ddagger(\%)$ & 61.7 & 61.2 & 60.8 & 61.3 & 62.0 & 62.3 & 60.7 & 60.3 & 61.0 & 61.6 & 62.5 \\
\hline Age at menarche (yrs) & 12.50 & 12.52 & 12.49 & 12.47 & 12.47 & 12.52 & 12.53 & $12.5 \mid$ & 12.48 & 12.49 & 12.50 \\
\hline Age at first birth (yrs) & 22.98 & 23.19 & 23.34 & 23.24 & 23.13 & 22.64 & 23.19 & 23.34 & 23.24 & 23.13 & 22.64 \\
\hline Parity (no. of children) & 2.01 & 1.90 & 1.92 & 1.94 & 2.00 & 2.09 & 1.87 & 1.78 & 1.78 & 1.90 & 2.19 \\
\hline Age at menopause(yrs) & 47.02 & 47.31 & 47.47 & 47.47 & 47.35 & 47.03 & 47.08 & 47.43 & 47.42 & 47.40 & 47.14 \\
\hline $\begin{array}{l}\text { Alcohol intake } \\
(g / d)\end{array}$ & 6.2 & 6.5 & 6.5 & 6.5 & 6.3 & 5.8 & 6.2 & 6.3 & 6.5 & 6.4 & 6.0 \\
\hline \multirow{2}{*}{$\begin{array}{l}\text { Moderate-to-vigorous } \\
\text { activity }\end{array}$} & & \multicolumn{5}{|c|}{ Ages $15-18$ years } & \multicolumn{5}{|c|}{ Ages $19-29$ years } \\
\hline & & $\begin{array}{l}\text { Neverl } \\
\text { Rarely }\end{array}$ & $<1 \mathrm{hr} / \mathrm{wk}$ & I-3 hrs/wk & 4-7 hrs/wk & $>7 \mathrm{hrs} / \mathrm{wk}$ & $\begin{array}{l}\text { Never/ } \\
\text { Rarely }\end{array}$ & $<1 \mathrm{hr} / \mathrm{wk}$ & I-3 hrs/wk & 4-7 hrs/wk & $>7 \mathrm{hrs} / \mathrm{wk}$ \\
\hline Participants, No. (\%) & 118899 & $15359(13)$ & $10080(9)$ & $25250(2 I)$ & $26429(22)$ & $39845(34)$ & $11585(10)$ & $9867(8)$ & $25686(22)$ & $30175(25)$ & $39603(33)$ \\
\hline Age at baseline (yrs) & 62.9 & 62.9 & 62.8 & 62.9 & 62.8 & 62.8 & 62.8 & 62.5 & 62.6 & 62.8 & 63.2 \\
\hline BMI, current* $\left(\mathrm{kg} / \mathrm{m}^{2}\right)$ & 26.7 & 26.7 & 26.6 & 26.6 & 26.6 & 26.9 & 27.0 & 26.8 & 26.6 & 26.6 & 26.8 \\
\hline BMl at age $18^{*}\left(\mathrm{~kg} / \mathrm{m}^{2}\right)$ & 20.9 & 21.3 & 21.0 & 21.0 & 20.8 & 20.7 & 21.3 & 21.1 & 20.9 & 20.8 & 20.7 \\
\hline Caucasian (\%) & 91.2 & 90.4 & 91.1 & 91.4 & 92.0 & 91.6 & 88.8 & 90.6 & 91.1 & 92.1 & 92.3 \\
\hline College education (\%) & 31.5 & 30.5 & 31.5 & 32.4 & 33.7 & 30.7 & 33.7 & 36.3 & 35.3 & 32.8 & 27.0 \\
\hline $\begin{array}{l}\text { Family history of breast } \\
\text { cancert (\%) }\end{array}$ & 13.7 & 13.5 & 12.7 & 13.7 & 14.0 & 13.7 & 13.4 & 13.0 & 13.8 & 13.6 & 13.9 \\
\hline Current smoker (\%) & 13.4 & 10.1 & 10.9 & 12.7 & 13.4 & 15.7 & 10.6 & 11.2 & 12.0 & 13.4 & 15.7 \\
\hline Ever MHT use $\ddagger(\%)$ & 61.7 & 59.2 & 60.9 & 61.5 & 63.3 & 62.4 & 58.4 & 62.1 & 62.1 & 62.9 & 61.8 \\
\hline Age at menarche (yrs) & 12.50 & 12.42 & 12.45 & 12.48 & 12.50 & 12.55 & $|2.4|$ & 12.46 & 12.49 & 12.50 & 12.54 \\
\hline Age at first birth (yrs) & 22.98 & 23.32 & 23.26 & 23.18 & 23.03 & 22.66 & 23.56 & 23.54 & 23.40 & 23.04 & 22.45 \\
\hline Parity (no. of children) & 2.01 & 1.86 & 1.94 & 1.97 & 2.02 & 2.09 & 1.75 & 1.82 & 1.88 & 2.02 & 2.20 \\
\hline Age at menopause(yrs) & 47.02 & 47.43 & 47.52 & 47.46 & 47.30 & 46.99 & 47.49 & 47.64 & 47.54 & 47.30 & 46.96 \\
\hline $\begin{array}{l}\text { Alcohol intake } \\
(g / d)\end{array}$ & 6.2 & 6.0 & 6.2 & 6.3 & 6.4 & 6.1 & 6.0 & 6.1 & 6.3 & 6.3 & 6.1 \\
\hline
\end{tabular}

*BMI: body mass index.

†Family history of breast cancer in a first-degree female relative.

$\ddagger$ MHT: menopausal hormone therapy. 
ity, the most active women reported that they were leaner at age 18 years than inactive women. Women with a high level of physical activity in the past 10 years were less likely to currently smoke cigarettes and more likely to drink alcohol than inactive women; however, compared with less active women, those with the highest level of activity from ages $15-18,19-29$ or 35-39 years were more likely to be current cigarette smokers.

Positive correlations were observed between light and moderate-to-vigorous intensity activity within the same periods of life ( $\rho=0.49-0.53$ ) (Table 3 ). Regardless of intensity level, correlations were modest between physical activity in the past 10 years and activity from ages $15-18$ years ( $\rho=0.35$ for light activity, $\rho=0.28$ for moderate-tovigorous activity), but were stronger for less distant life periods of activity such as ages 19-29 and 35-39 years ( $\rho=$ 0.79 for both light and moderate-to-vigorous activity).

Over 6.6 years of follow-up, 4287 incident breast cancers were diagnosed (including 736 in situ tumors). The majority of tumors with known ER status were ER-positive $(84 \%, \mathrm{n}=1352)$. Women diagnosed with incident breast cancer were more likely than those who were not diagnosed with breast cancer to have a first-degree female relative with breast cancer and to report an earlier age at menarche, later age at first birth, lower parity, later age at menopause, slightly higher BMI, increased alcohol intake and to have ever used MHT (data not shown).

We did not observe an association of physical activity from ages 15-18, 19-29, or 35-39 years with postmenopausal breast cancer risk, regardless of intensity level (Tables 4 \&5). Physical activity of moderate-to-vigorous intensity during the past 10 years was statistically significantly associated with reduced risk of postmenopausal breast cancer (Table 5). Specifically, women engaging in $>7$ hours per week of moderate-to-vigorous activity showed a $16 \%$ reduced breast cancer risk as compared with their inactive counterparts in both age-adjusted (RR: 0.84, 95\%CI:0.76,0.93) and multivariate (RR:0.84, 95\%CI:0.76,0.93) analyses. Additional adjustment for light intensity activity during the same time period did not substantially alter risk estimates (RR: 0.85, 95\%CI:0.76,0.95), and adjustment for current BMI slightly attenuated but did not abolish the multivariate association (RR:0.87, 95\%CI:0.78,0.96).

Including variables representing BMI at age 18 years, history of mammography, previous benign breast disease, or excluding age at menarche in serial multivariate models did not change risk estimates. No statistically significant heterogeneity in the association of physical activity with breast cancer risk was observed across strata of baseline BMI, BMI at age 18 years, family history of breast cancer, parity, or menopausal hormone therapy use (data not shown).

Physical activity from ages 15-18, 19-29 and 35-39 years was not associated with breast cancer tumor characteristics (Tables 6 \&7). Results are shown for multivariate models without BMI, as addition of BMI to statistical models did not substantially alter risk estimates. More than 7 hours per week of moderate-to-vigorous physical activity during the past 10 years was statistically significantly associated with reduced risk of ER-positive tumors (Table 7, RR:0.77, 95\%CI:0.64,0.92). The observed relationship with ER-negative tumors for $>7$ hours per week of moderate-to-vigorous activity during the past 10 years was also inverse (RR: 0.87, 95\%CI:0.58,1.29), but failed to reach statistical significance. Inverse associations with moderate-to-vigorous activity in the past ten years were of similar magnitude for both invasive (RR:0.84, 95\%CI:0.75,0.94) and in situ (RR:0.85, 95\%CI:0.66,1.08) tumors, and associations did not vary by tumor histology (data not shown).

\section{Discussion}

We observed that $>7$ hour per week of recent (in the past 10 years) but not historical (from ages 15-18, 19-29, or 35-39 years) moderate-to-vigorous intensity physical activity was associated with a $16 \%$ reduced risk of postmenopausal breast cancer. No relation between breast cancer risk and light intensity physical activity during any of the periods of life examined was observed. Associations did not appear to vary by ER status, breast tumor stage, or tumor histological subtype.

The inverse association observed in our study (RR:0.84, $95 \%$ CI:0.76,0.93) is similar to the $13 \%$ reduction in postmenopausal breast cancer risk (RR:0.87, 95\%CI:0.81,0.95) observed for women reporting $\geq 5$ episodes per week of physical activity during the year preceding assessment in the baseline NIH-AARP cohort [24]. Although both of these risk estimates are less pronounced than the $20-40 \%$ risk reductions reported in reviews of the physical activitybreast cancer relationship $[3,5]$, directly comparing risk estimates across studies is difficult considering variation in the instruments used to measure physical activity, inconsistencies in the parameters of physical activity that are assessed, and underlying differences in the study populations.

Only two previous studies $[7,14]$ reported on both the intensity level and time of life of physical activity in relation to breast cancer risk. A Polish case-control study [14] evaluated the association of physical activity of various intensities from light to vigorous across decades of life (age 20-24, 25-29, 30-34, 35-39, 40-49, 50-59, 60-69 years). Significant inverse associations were observed for physical activity across multiple decades of life with risk of breast cancer. 
Table 2: Characteristics of the study population by light and moderate-to-vigorous intensity physical activity during two periods of life: II 8,899 postmenopausal women in the NIH-AARP Diet and Health Study

\begin{tabular}{|c|c|c|c|c|c|c|c|c|c|c|c|}
\hline \multirow[t]{2}{*}{ Light activity } & \multirow[t]{2}{*}{ Total } & \multicolumn{5}{|c|}{ Ages $35-39$ years } & \multicolumn{5}{|c|}{ Past 10 years } \\
\hline & & $\begin{array}{l}\text { Neverl } \\
\text { Rarely }\end{array}$ & $<\mathrm{l} \mathrm{hr} / \mathrm{wk}$ & I-3 hrs/wk & 4-7 hrs/wk & $>7$ hrs/wk & $\begin{array}{l}\text { Neverl } \\
\text { Rarely }\end{array}$ & $<\mathrm{l} \mathrm{hr/wk}$ & I-3 hrs/wk & 4-7 hrs/wk & $>7 \mathrm{hrs} / \mathrm{wk}$ \\
\hline Participants, No. (\%) & 118899 & $5189(4)$ & $6121(5)$ & $20710(17)$ & $29018(24)$ & $55602(47)$ & $5789(5)$ & $6811(6)$ & $24450(2 I)$ & $32432(27)$ & $47827(40)$ \\
\hline Age at baseline (yrs) & 62.9 & 62.6 & 62.2 & 62.4 & 62.6 & 63.3 & 62.5 & 62.3 & 62.4 & 62.9 & 63.2 \\
\hline BMI, current* $\left(\mathrm{kg} / \mathrm{m}^{2}\right)$ & 26.7 & 27.0 & 27.3 & 26.8 & 26.7 & 26.6 & 28.6 & 28.4 & 27.4 & 26.6 & 26.0 \\
\hline BMl at age $18 *\left(\mathrm{~kg} / \mathrm{m}^{2}\right)$ & 20.9 & 21.1 & 21.1 & 21.0 & 20.9 & 20.8 & 21.3 & 21.1 & 21.0 & 20.8 & 20.8 \\
\hline Caucasian (\%) & 91.2 & 85.3 & 85.8 & 89.5 & 91.8 & 93.1 & 84.9 & 85.0 & 90.0 & 92.3 & 93.1 \\
\hline College education (\%) & 31.5 & 31.8 & 33.6 & 35.0 & 34.3 & 28.9 & 27.5 & 29.8 & 34.0 & 33.8 & 29.6 \\
\hline $\begin{array}{l}\text { Family history of breast cancer }{ }^{\dagger} \\
(\%)\end{array}$ & 13.7 & 13.1 & 13.8 & 13.4 & 13.5 & 13.9 & 13.6 & 13.3 & 13.4 & 13.6 & 13.8 \\
\hline Current smoker (\%) & 13.4 & 12.6 & 12.8 & 13.3 & 13.1 & 13.7 & 16.7 & 15.1 & 13.7 & 12.9 & 12.9 \\
\hline Ever MHT use $\ddagger$ (\%) & 61.7 & 59.0 & 58.7 & 61.6 & 62.5 & 62.1 & 56.9 & 58.3 & 61.8 & 62.8 & 62.0 \\
\hline Age at menarche (yrs) & 12.50 & $12.5 \mid$ & 12.48 & 12.48 & 12.48 & $12.5 \mid$ & 12.48 & 12.47 & 12.47 & 12.48 & 12.53 \\
\hline Age at first birth (yrs) & 22.98 & 22.98 & 23.33 & 23.30 & 23.23 & 22.73 & 22.75 & 23.04 & 23.20 & 23.14 & 22.81 \\
\hline Parity (no. of children) & 2.01 & 1.87 & 1.79 & 1.77 & 1.90 & 2.19 & 1.92 & 1.88 & 1.89 & 1.98 & 2.11 \\
\hline Age at menopause(yrs) & 47.02 & 47.01 & 47.31 & 47.32 & 47.34 & 47.24 & 46.59 & 47.00 & 47.20 & 47.43 & 47.34 \\
\hline $\begin{array}{l}\text { Alcohol intake } \\
\text { (g/d) }\end{array}$ & 6.2 & 6.0 & 6.1 & 6.3 & 6.4 & 6.1 & 6.1 & 5.5 & 6.1 & 6.3 & 6.2 \\
\hline \multirow[t]{2}{*}{ Moderate-to-vigorous activity } & & \multicolumn{5}{|c|}{ Ages $35-39$ years } & \multicolumn{5}{|c|}{ Past 10 years } \\
\hline & & $\begin{array}{l}\text { Never/ } \\
\text { Rarely }\end{array}$ & $<1 \mathrm{hr} / \mathrm{wk}$ & $\mathrm{I}-3 \mathrm{hrs} / \mathrm{wk}$ & 4-7 hrs/wk & $>7 \mathrm{hrs} / \mathrm{wk}$ & $\begin{array}{r}\text { Never/ } \\
\text { Rarely }\end{array}$ & $<1 \mathrm{hr} / \mathrm{wk}$ & $\mathrm{I}-3 \mathrm{hrs} / \mathrm{wk}$ & 4-7 hrs/wk & $>7 \mathrm{hrs} / \mathrm{wk}$ \\
\hline Participants, No. (\%) & 118899 & $10868(9)$ & 10507 (9) & $26715(23)$ & $31560(27)$ & $37477(32)$ & $17028(14)$ & $12498(11)$ & $29927(25)$ & $30231(25)$ & $282 \mid 4(24)$ \\
\hline Age at baseline (yrs) & 62.9 & 62.8 & 62.5 & 62.5 & 62.7 & 63.4 & 62.9 & 62.5 & 62.7 & 62.9 & 63.1 \\
\hline BMI, current* $\left(\mathrm{kg} / \mathrm{m}^{2}\right)$ & 26.7 & 27.6 & 27.3 & 26.8 & 26.5 & 26.4 & 28.7 & 28.0 & 26.9 & 26.0 & 25.4 \\
\hline BMl at age $18^{*}\left(\mathrm{~kg} / \mathrm{m}^{2}\right)$ & 20.9 & 21.3 & 21.0 & 20.9 & 20.8 & 20.7 & 21.2 & 21.0 & 20.8 & 20.8 & 20.7 \\
\hline Caucasian (\%) & 91.2 & 88.0 & 89.1 & 90.9 & 92.6 & 92.6 & 88.7 & 89.7 & 91.4 & 92.7 & 92.4 \\
\hline College education (\%) & 31.5 & 33.2 & 35.8 & 35.7 & 33.0 & 26.4 & 30.3 & 31.8 & 33.7 & 33.7 & 27.9 \\
\hline $\begin{array}{l}\text { Family history of breast cancer }{ }^{\dagger} \\
(\%)\end{array}$ & 13.7 & 13.0 & 13.4 & 13.7 & 13.6 & 14.0 & 13.3 & 13.9 & 13.4 & 14.1 & 13.6 \\
\hline Current smoker (\%) & 13.4 & 12.0 & 12.3 & 12.5 & 13.3 & 14.8 & 15.5 & 14.3 & 13.6 & 12.6 & 12.5 \\
\hline Ever MHT use $\ddagger$ (\%) & 61.7 & 56.7 & 60.1 & 63.0 & 63.3 & 61.8 & 57.8 & 60.8 & 62.1 & 64.1 & 61.6 \\
\hline Age at menarche (yrs) & 12.50 & 12.38 & 12.48 & 12.48 & 12.49 & 12.55 & 12.40 & 12.46 & 12.48 & 12.52 & 12.56 \\
\hline Age at first birth (yrs) & 22.98 & 23.39 & 23.40 & 23.25 & 23.02 & 22.60 & 23.06 & 23.06 & 23.07 & 23.06 & 22.76 \\
\hline Parity (no. of children) & 2.01 & 1.74 & 1.81 & 1.89 & 2.02 & 2.22 & 1.88 & 1.95 & 1.99 & 2.04 & 2.09 \\
\hline Age at menopause(yrs) & 47.02 & 47.39 & 47.42 & 47.42 & 47.33 & 47.05 & 46.94 & 47.17 & 47.34 & 47.40 & 47.26 \\
\hline $\begin{array}{l}\text { Alcohol intake } \\
(\mathrm{g} / \mathrm{d})\end{array}$ & 6.2 & 5.7 & 5.9 & 6.3 & 6.5 & 6.2 & 5.8 & 5.8 & 6.1 & 6.4 & 6.5 \\
\hline
\end{tabular}

*BMI: body mass index.

†Family history of breast cancer in a first-degree female relative.

$\ddagger$ MHT: menopausal hormone therapy. 
Inverse associations were generally stronger for moderateto-vigorous recreational activity than for total recreational activity, and a high level of moderate-to-vigorous recreational activity during ages 50-59 years was associated with the largest reduction in breast cancer risk.

In the second study to look at the combination of intensity and time in life of physical activity [7], the California Teachers' Study (CTS) investigated moderate and strenuous intensity physical activity from ages 18-24, 25-34, 35-44, 45-54 years and in the 3 years preceding baseline assessment. Contrasting the Polish case-control study [14] and our results, the CTS [7] observed no association of moderate or strenuous physical activity during the three years preceding baseline with breast cancer risk. Yet a high versus low level of strenuous physical activity from age 18 years through the three years preceding baseline was associated with a 20\% reduced risk of breast cancer (RR:0.80, 95\%CI:0.69-0.94), and moderate physical activity from age 18 years through the three years preceding baseline showed a statistically non-significant $6 \%$ reduced breast cancer risk (RR:0.94, 95\%CI:0.81-1.08) [7]. As the relation of physical activity with breast cancer risk appears to vary by menopausal status [5], inconsistent results may be due to differences in the study populations; whereas our study included only postmenopausal women, and the Polish case-control study was comprised of $70.5 \%$ postmenopausal women, only $51.4 \%$ of women in the CTS were postmenopausal.

Our observation that recent physical activity showed a stronger inverse association with breast cancer risk than historical activity is supported by two systematic reviews $[3,5]$ and three prospective studies among postmenopausal women $[12,19,20]$. Furthermore, our finding that moderate-to-vigorous but not light physical activity was inversely related to breast cancer risk is supported by some [9,14,19], but not all $[10,13]$, studies on the topic. Many previous reports of the relation of physical activity intensity with breast cancer risk have compared moderate with vigorous physical activity; numerous studies [5-9,19] have shown stronger associations for vigorous intensity activity, but other studies have not found a dose-response according to physical activity intensity [10-18]. The physical activity questionnaire in our study combined moderate and vigorous intensity categories, which is consistent with the intensity level cited in the current public health recommendations [31,32]. However, we could not evaluate heterogeneity in the association of moderate versus vigorous activity with breast cancer risk within our study in order to compare with prior studies or to determine whether moderate activity is sufficient for reducing postmenopausal breast cancer risk.

The observed protective effect of moderate-to-vigorous physical activity in our study is biologically plausible, as there is some evidence that a high intensity of physical activity is associated with a reduction in estradiol [33] and enhanced sensitivity to insulin [34]. Whereas recent studies suggest that in postmenopausal women the effect of physical activity on estrogens may be mediated by loss of body fat $[35,36]$, the lack of confounding by or interaction with BMI in our study supports an independent influence of physical activity. Physical activity also appears to modulate immunity in a manner in which moderate activity is beneficial to the immune response, but sedentary behavior and highly strenuous activity can impair immune function [37].

We observed very little heterogeneity in the relation of physical activity to breast cancer tumor characteristics, regardless of the intensity or time of life of physical activity. A lack of heterogeneity in the relationship of physical activity with ER-defined breast cancer is consistent with the Breast Cancer Detection Demonstration Project cohort study [6] and five case-control studies [14,15,38-40]. However, other studies have reported stronger inverse associations of physical activity with ER-positive tumors $[14,41,42]$ or ER-negative tumors $[5,7,24]$. A suggested inverse relation of recent moderate-to-vigorous activity

Table 3: Spearman correlation coefficients for the relationship among physical activity variables

\begin{tabular}{|c|c|c|c|c|c|c|c|}
\hline \multirow{3}{*}{$\begin{array}{l}\text { Physical activity, by intensity and } \\
\text { period of life } \\
\text { Light physical activity }\end{array}$} & \multicolumn{7}{|c|}{ Physical activity, by intensity and period of life } \\
\hline & \multicolumn{3}{|c|}{ Light physical activity } & \multicolumn{4}{|c|}{ Moderate-to-vigorous physical activity } \\
\hline & $15-18$ years & $19-29$ years & $35-39$ years & $15-18$ years & $19-29$ years & $35-39$ years & Past 10 years \\
\hline $15-18$ years & - & 0.65 & 0.52 & 0.53 & 0.41 & 0.30 & 0.12 \\
\hline $19-29$ years & 0.65 & - & 0.79 & 0.38 & 0.50 & 0.42 & 0.21 \\
\hline $35-39$ years & 0.52 & 0.79 & - & 0.31 & 0.44 & 0.49 & 0.29 \\
\hline \multirow[t]{2}{*}{ Past 10 years } & 0.35 & 0.53 & 0.66 & 0.21 & 0.32 & 0.39 & 0.49 \\
\hline & \multicolumn{3}{|c|}{ Moderate-to-vigorous physical activity } & & & & \\
\hline $\begin{array}{l}\text { Moderate-to-vigorous physical } \\
\text { activity }\end{array}$ & $15-18$ years & $19-29$ years & $35-39$ years & & & & \\
\hline $15-18$ years & - & 0.69 & 0.53 & & & & \\
\hline $19-29$ years & 0.69 & - & 0.79 & & & & \\
\hline $35-39$ years & 0.53 & 0.79 & - & & & & \\
\hline Past 10 years & 0.28 & 0.45 & 0.61 & & & & \\
\hline
\end{tabular}


Table 4: Relative risk (RR) and $95 \%$ confidence intervals $(\mathrm{Cl})$ for the association of light physical activity during four periods of life with breast cancer incidence: I 18,899 postmenopausal women in the NIH-AARP Diet and Health Study

\begin{tabular}{|c|c|c|c|c|c|c|c|c|c|c|c|c|}
\hline \multirow{2}{*}{$\begin{array}{l}\text { Light activity } \\
\text { Ages } 15 \text { - } 18 \text { years }\end{array}$} & \multirow[t]{2}{*}{$\begin{array}{l}\text { No. } \\
\text { cancers* } \\
n=4287\end{array}$} & \multirow[t]{2}{*}{$\mathbf{R R}^{\dagger}$} & \multirow[t]{2}{*}{$\begin{array}{c}95 \% \\
\mathbf{C l}\end{array}$} & \multirow[t]{2}{*}{$\mathbf{R R}+\dagger$} & \multicolumn{2}{|c|}{$\begin{array}{c}95 \% \\
\mathbf{C l}\end{array}$} & \multirow[t]{2}{*}{$\mathbf{R R} \S$} & \multicolumn{2}{|c|}{$\begin{array}{c}95 \% \\
\mathrm{Cl}\end{array}$} & \multirow[t]{2}{*}{$\mathbf{R R}^{t}$} & \multicolumn{2}{|c|}{$\begin{array}{c}95 \% \\
\text { Cl }\end{array}$} \\
\hline & & & & & & & & & & & & \\
\hline Never/Rarely & 358 & $\mathrm{I} .00$ (ref.) & & 1.00 (ref.) & & & $\mathrm{I} .00$ (ref.) & & & 1.00 (ref.) & & \\
\hline$<$ l hour/week & 344 & 1.09 & $0.94,1.27$ & 1.09 & 0.94 & 1.26 & 1.07 & 0.92 & 1.24 & 1.09 & 0.94 & 1.26 \\
\hline I-3 hours/week & 974 & 1.06 & $0.94,1.20$ & 1.05 & 0.93 & 1.19 & 1.04 & 0.92 & 1.18 & 1.05 & 0.93 & 1.18 \\
\hline 4-7 hours/week & 982 & 1.08 & $0.96,1.22$ & 1.08 & 0.95 & 1.22 & 1.07 & 0.95 & 1.22 & 1.07 & 0.95 & 1.21 \\
\hline$>7$ hours/week & 1553 & 1.03 & $0.92,1.16$ & 1.05 & 0.94 & 1.18 & 1.05 & 0.93 & 1.19 & 1.04 & 0.93 & 1.17 \\
\hline \multicolumn{13}{|l|}{ Ages $19-29$ years } \\
\hline Never/Rarely & 199 & 1.00 (ref.) & & 1.00 (ref.) & & & 1.00 (ref.) & & & 1.00 (ref.) & & \\
\hline$<$ I hour/week & 249 & 1.18 & $0.98,1.42$ & 1.16 & 0.97 & 1.40 & 1.15 & 0.95 & 1.38 & 1.16 & 0.96 & 1.40 \\
\hline I-3 hours/week & 793 & 1.14 & $0.98,1.34$ & 1.11 & 0.95 & 1.30 & 1.10 & 0.94 & 1.29 & 1.11 & 0.95 & 1.30 \\
\hline 4-7 hours/week & 1036 & 1.13 & $0.97,1.32$ & 1.12 & 0.96 & 1.30 & 1.11 & 0.95 & 1.30 & 1.11 & 0.96 & 1.30 \\
\hline$>7$ hours/week & 1940 & 1.05 & $0.91,1.21$ & 1.07 & 0.93 & 1.24 & 1.07 & 0.92 & 1.25 & 1.07 & 0.92 & 1.24 \\
\hline \multicolumn{13}{|l|}{ Ages $35-39$ years } \\
\hline Never/Rarely & 171 & 1.00 (ref.) & & 1.00 (ref.) & & & $\mathrm{I} .00$ (ref.) & & & 1.00 (ref.) & & \\
\hline$<$ l hour/week & 238 & 1.19 & $0.98,1.44$ & 1.17 & 0.96 & 1.42 & 1.14 & 0.94 & 1.40 & 1.16 & 0.95 & 1.41 \\
\hline I-3 hours/week & 811 & 1.19 & $1.01,1.41$ & 1.15 & 0.98 & 1.36 & 1.15 & 0.97 & 1.36 & 1.15 & 0.98 & 1.36 \\
\hline 4-7 hours/week & 1036 & 1.08 & $0.92,1.27$ & 1.05 & 0.89 & 1.24 & 1.04 & 0.88 & 1.23 & 1.05 & 0.91 & 1.24 \\
\hline$>7$ hours/week & 1952 & 1.05 & $0.90,1.23$ & 1.06 & 0.90 & 1.24 & 1.06 & 0.90 & 1.24 & 1.06 & 0.91 & 1.24 \\
\hline \multicolumn{13}{|l|}{ Past 10 years } \\
\hline Never/Rarely & 183 & I.00 (ref.) & & 1.00 (ref.) & & & $\mathrm{I} .00$ (ref.) & & & 1.00 (ref.) & & \\
\hline <। hour/week & 266 & 1.23 & I.02, I.48 & 1.21 & 1.00 & 1.46 & 1.19 & 0.98 & 1.44 & 1.21 & 1.00 & 1.46 \\
\hline I-3 hours/week & 890 & 1.13 & $0.96,1.32$ & 1.08 & 0.92 & 1.27 & 1.10 & 0.93 & 1.29 & 1.09 & 0.93 & 1.28 \\
\hline 4-7 hours/week & 1264 & 1.20 & $1.02,1.40$ & 1.14 & 0.98 & 1.34 & 1.19 & 1.01 & 1.39 & 1.16 & 0.99 & 1.36 \\
\hline$>7$ hours/week & 1634 & 1.04 & $0.89,1.21$ & 1.01 & 0.87 & 1.18 & 1.09 & 0.92 & 1.28 & 1.04 & 0.89 & 1.21 \\
\hline
\end{tabular}

* Number of cancer cases may not add up to total $(n=4287)$ due to missing physical activity values

† Relative risks adjusted for age (continuous)

†† Relative risks adjusted for: age (continuous); race/ethnicity (white, black, Hispanic, Asian/Pacific Islander/American Indian); education level (<12 years or high school equivalent, 12 years or high school equivalent, post-high school vocational or technical training, some college, college graduate, post-graduate); smoking status (non-smoker, former, current); alcohol intake (grams/day, quintiles adjusted for total energy intake); family history of breast cancer (no, yes); age at menarche (<13, 13-14, $\geq 15$ years); age at first birth (nulliparous, $<20,20-24,25-29,30+$ years); parity (number of children: $0,1-2,3$ or more); age at menopause $(<40,40-44,45-49,50-54, \geq 55$ years); menopausal hormone use (never, ever)

$\S$ Relative risks additionally adjusted for frequency of other type of physical activity (either light or moderate-to-vigorous) during that same time period

$£$ Relative risks additionally adjusted for body mass index (BMI: $<25.0,25.0-29.9,30.0-34.9, \geq 35.0 \mathrm{~kg} / \mathrm{m}^{2}$ )

with ER-negative tumors was observed in both the current study and the baseline NIH-AARP cohort [24]. Yet the substantially smaller number of ER-negative breast cancer cases in the present study likely limited our ability to detect heterogeneity by ER-status.

In addition, we observed similar associations for recent moderate-to-vigorous physical activity with invasive and in situ breast cancer. This finding is consistent with three cohort studies $[7,12,24]$ and four case-control studies $[14,38,43,44]$, but diverges somewhat from the Cancer Prevention Study II (CPSII) [20] and a German case-control study [41] in which no association was apparent between recent recreational physical activity and in situ breast cancer. However, each of these studies $[20,41]$ included only
205 in situ tumors and thus may have lacked power to detect an association.

Observation of similar associations of moderate-to-vigorous activity during the past 10 years with ductal and lobular histological subtypes in our study corresponds to results from a Polish case-control study [14]. These results suggest that moderate-to-vigorous intensity physical activity influences postmenopausal breast cancer risk through estrogenic and non-estrogenic pathways, in both early and more advanced tumors, and affects tumors of a variety of histological subtypes.

Strengths of our study include the large sample size, the prospective design, and the information on timing and intensity of physical activity. In addition, with the availabil- 
Table 5: Relative risk (RR) and $95 \%$ confidence intervals $(\mathrm{Cl})$ for the association of moderate-to-vigorous physical activity during four periods of life with breast cancer incidence: I 18,899 postmenopausal women in the NIH-AARP Diet and Health Study

\begin{tabular}{|c|c|c|c|c|c|c|c|c|c|c|c|c|}
\hline \multirow[b]{2}{*}{ Ages $15-18$ years } & \multirow[t]{2}{*}{$\begin{array}{l}\text { No. } \\
\text { cancers* } \\
n=4287\end{array}$} & \multirow[t]{2}{*}{$\mathbf{R R}^{\dagger}$} & \multirow[t]{2}{*}{$\begin{array}{c}95 \% \\
\mathbf{C l}\end{array}$} & \multirow[t]{2}{*}{$\mathbf{R R}+\dagger$} & \multicolumn{2}{|c|}{$\begin{array}{c}95 \% \\
\mathrm{Cl}\end{array}$} & \multirow[t]{2}{*}{$\mathbf{R R}^{\S}$} & \multicolumn{2}{|c|}{$\begin{array}{c}95 \% \\
\mathbf{C l}\end{array}$} & \multirow[t]{2}{*}{$\mathbf{R R}^{t}$} & \multicolumn{2}{|c|}{$\begin{array}{c}95 \% \\
\mathrm{Cl}\end{array}$} \\
\hline & & & & & & & & & & & & \\
\hline Never/Rarely & 541 & $\mathrm{I} .00$ (ref.) & & $\mathrm{I} .00$ (ref.) & & & 1.00 (ref.) & & & 1.00 (ref.) & & \\
\hline$<$ l hour/week & 394 & 1.11 & $0.98,1.27$ & 1.12 & 0.98 & 1.27 & 1.10 & 0.97 & 1.26 & 1.12 & 0.98 & 1.27 \\
\hline I-3 hours/week & 936 & 1.05 & $0.95,1.17$ & 1.05 & 0.94 & 1.17 & 1.04 & 0.93 & 1.16 & 1.05 & 0.94 & 1.16 \\
\hline 4-7 hours/week & 950 & 1.02 & $0.92,1.14$ & 1.01 & 0.91 & 1.13 & 1.00 & 0.89 & 1.12 & 1.01 & 0.91 & 1.13 \\
\hline$>7$ hours/week & 1415 & 1.02 & $0.92,1.12$ & 1.03 & 0.93 & 1.14 & 1.02 & 0.91 & 1.14 & 1.02 & 0.93 & 1.13 \\
\hline \multicolumn{13}{|l|}{ Ages $19-29$ years } \\
\hline Never/Rarely & 415 & 1.00 (ref.) & & 1.00 (ref.) & & & 1.00 (ref.) & & & 1.00 (ref.) & & \\
\hline <। hour/week & 384 & 1.09 & $0.95,1.25$ & 1.08 & 0.94 & 1.24 & 1.07 & 0.93 & 1.23 & 1.08 & 0.94 & 1.24 \\
\hline I-3 hours/week & 976 & 1.07 & $0.95,1.20$ & 1.06 & 0.94 & 1.19 & 1.05 & 0.93 & 1.18 & 1.06 & 0.94 & 1.19 \\
\hline 4-7 hours/week & 1080 & 1.00 & $0.89,1.12$ & 1.01 & 0.90 & 1.13 & 1.01 & 0.89 & 1.13 & 1.01 & 0.90 & 1.13 \\
\hline$>7$ hours/week & 1375 & 0.97 & $0.87,1.08$ & 1.01 & 0.90 & 1.13 & 1.02 & 0.90 & 1.15 & 1.01 & 0.90 & 1.13 \\
\hline \multicolumn{13}{|l|}{ Ages 35-39 years } \\
\hline Never/Rarely & 392 & 1.00 (ref.) & & 1.00 (ref.) & & & 1.00 (ref.) & & & 1.00 (ref.) & & \\
\hline <। hour/week & 421 & 1.12 & $0.98,1.28$ & 1.11 & 0.97 & 1.27 & 1.09 & 0.95 & 1.25 & 1.11 & 0.97 & 1.27 \\
\hline I-3 hours/week & 963 & 1.00 & $0.89,1.13$ & 0.99 & 0.88 & 1.11 & 0.98 & 0.87 & 1.11 & 0.99 & 0.88 & 1.12 \\
\hline 4-7 hours/week & 1174 & 1.03 & $0.92,1.16$ & 1.03 & 0.92 & 1.15 & 1.04 & 0.92 & 1.18 & 1.04 & 0.93 & 1.16 \\
\hline$>7$ hours/week & 1288 & 0.94 & $0.84,1.06$ & 0.97 & 0.87 & 1.09 & 0.99 & 0.87 & 1.12 & 0.98 & 0.88 & 1.10 \\
\hline \multicolumn{13}{|l|}{ Past 10 years } \\
\hline Never/Rarely & 646 & 1.00 (ref.) & & 1.00 (ref.) & & & 1.00 (ref.) & & & 1.00 (ref.) & & \\
\hline <। hour/week & 507 & 1.06 & $0.94,1.19$ & 1.05 & 0.94 & 1.18 & 1.03 & 0.92 & 1.16 & 1.06 & 0.94 & 1.19 \\
\hline I-3 hours/week & 1071 & 0.93 & $0.84,1.02$ & 0.91 & 0.83 & 1.00 & 0.90 & 0.81 & 1.00 & 0.93 & 0.84 & 1.02 \\
\hline 4-7 hours/week & 1106 & 0.94 & $0.86,1.04$ & 0.92 & 0.83 & 1.01 & 0.91 & 0.82 & 1.01 & 0.94 & 0.85 & 1.04 \\
\hline$>7$ hours/week & 928 & 0.84 & $0.76,0.93$ & 0.84 & 0.76 & 0.93 & 0.85 & 0.76 & 0.95 & 0.87 & 0.78 & 0.96 \\
\hline
\end{tabular}

Number of cancer cases may not add up to total $(n=4287)$ due to missing physical activity values

$\dagger$ Relative risks adjusted for age (continuous)

†† Relative risks adjusted for: age (continuous); race/ethnicity (white, black, Hispanic, Asian/Pacific Islander/American Indian); education level (<12 years or high school equivalent, 12 years or high school equivalent, post-high school vocational or technical training, some college, college graduate, post-graduate); smoking status (non-smoker, former, current); alcohol intake (grams/day, quintiles adjusted for total energy intake); family history of breast cancer (no, yes); age at menarche ( $<13,13-14, \geq 15$ years); age at first birth (nulliparous, $<20,20-24,25-29,30+$ years); parity (number of children: 0 , I-2, 3 or more); age at menopause ( $<40,40-44,45-49,50-54, \geq 55$ years); menopausal hormone use (never, ever)

$\S$ Relative risks additionally adjusted for frequency of other type of physical activity (either light or moderate-to-vigorous) during that same time period

$£$ Relative risks additionally adjusted for body mass index (BMI: $<25.0,25.0-29.9,30.0-34.9, \geq 35.0 \mathrm{~kg} / \mathrm{m}^{2}$ )

ity of detailed questionnaire data regarding breast cancer risk factors, we could control for potential confounding variables. While our physical activity questionnaire was not directly validated, the inverse associations we observed between recent physical activity and BMI and recent physical activity and current cigarette smoking suggest construct validity of our instrument. Furthermore, our physical activity categories classified $49 \%$ of women in our study as achieving the current public health recommendation of at least 2.5 hours per week of moderate-to-vigorous physical activity to maintain health $[31,32]$, comparable to the $47.5 \%$ of U.S. women estimated to achieve this level of activity in a 2007 national survey [45]. One limitation of our study, however, is that the generalizability of our results may be limited due to the relatively low response proportion to our initial postal questionnaire.
In our cohort of postmenopausal women, we were able to examine the relation of physical activity intensity across the lifespan to postmenopausal breast cancer risk, but we relied upon recall of physical activity during time periods in the distant past. Prior studies have shown reasonably strong correlations between physical activity recalled from 3-5 years [46] and 15 years [47] in the past with physical activity measured objectively at that time, although the validity of physical activity over longer periods of recall is not known. Our observation that physical activity was positively correlated across proximate age periods suggests that our ability to discriminate between certain age periods may have been limited. Furthermore, it is likely that the null associations with historical physical activity in our study resulted from a greater degree of misclassification of historical than recent physical activity. 
Table 6: Multivariate adjusted relative risk (RR)* and $95 \%$ confidence intervals $(\mathrm{Cl})$ for the association of light physical activity during four periods of life with breast cancer tumor characteristics: I 18,899 postmenopausal women in the NIH-AARP Diet and Health Study

\begin{tabular}{|c|c|c|c|c|c|c|c|c|c|c|c|c|c|c|c|c|c|c|}
\hline \multirow{2}{*}{$\begin{array}{l}\text { Light activity } \\
\text { Ages } 15 \text { - } 18 \text { years }\end{array}$} & \multirow[t]{2}{*}{$\begin{array}{l}\text { ER- } \\
\text { positive } \\
\text { tRR }\end{array}$} & \multicolumn{2}{|c|}{$\begin{array}{c}95 \% \\
\text { Cl }\end{array}$} & \multirow{3}{*}{$\begin{array}{c}\begin{array}{c}\text { ER- } \\
\text { negative } \\
\text { RR }\end{array} \\
1.00 \text { (ref.) }\end{array}$} & \multicolumn{2}{|c|}{$\begin{array}{c}95 \% \\
\text { Cl }\end{array}$} & \multirow[t]{2}{*}{$\mathbf{p}^{\dagger \dagger}$} & \multirow[t]{2}{*}{$\begin{array}{c}\text { ER- } \\
\text { unknown } \\
\text { RR }\end{array}$} & \multicolumn{2}{|c|}{$\begin{array}{c}95 \% \\
\mathrm{Cl}\end{array}$} & \multirow[t]{2}{*}{$\mathbf{p}^{\S}$} & \multirow[t]{2}{*}{$\begin{array}{c}\text { Invasive } \\
\text { RR }\end{array}$} & \multicolumn{2}{|c|}{$\begin{array}{c}95 \% \\
\mathrm{Cl}\end{array}$} & \multirow[t]{2}{*}{$\begin{array}{l}\text { In } \\
\text { situ } \\
\text { RR }\end{array}$} & \multicolumn{2}{|c|}{$\begin{array}{c}95 \% \\
\text { Cl }\end{array}$} & \multirow[t]{2}{*}{$\mathbf{p}^{ \pm}$} \\
\hline & & & & & & & & & & & & & & & & & & \\
\hline Never/Rarely & $\mathrm{I} .00$ (ref.) & & & & & & & $\mathrm{I} .00$ (ref.) & & & & $\mathrm{I} .00$ (ref.) & & & 1.00 (ref.) & & & \\
\hline <। hour/week & 0.99 & 0.75 & 1.29 & 1.03 & 0.56 & 1.90 & & 1.28 & 1.03 & 1.60 & & 1.14 & 0.97 & 1.35 & 0.90 & 0.63 & 1.27 & \\
\hline I-3 hours/week & 0.97 & 0.78 & 1.21 & 1.07 & 0.65 & 1.74 & & 1.10 & 0.91 & 1.33 & & 1.04 & 0.91 & 1.20 & 1.06 & 0.81 & 1.39 & \\
\hline 4-7 hours/week & 1.06 & 0.86 & 1.31 & 1.11 & 0.68 & 1.81 & & 1.13 & 0.94 & 1.36 & & 1.10 & 0.96 & 1.26 & 0.99 & 0.75 & 1.30 & \\
\hline$>7$ hours/week & 1.09 & 0.89 & 1.33 & 1.02 & 0.64 & 1.62 & 0.79 & 1.13 & 0.95 & 1.35 & 0.90 & 1.10 & 0.97 & 1.26 & 0.81 & 0.62 & 1.06 & 0.03 \\
\hline \multicolumn{19}{|l|}{ Ages 19-29 years } \\
\hline Never/Rarely & $\mathrm{I} .00$ (ref.) & & & 1.00 (ref.) & & & & $\mathrm{I} .00$ (ref.) & & & & 1.00 (ref.) & & & 1.00 (ref.) & & & \\
\hline <I hour/week & 1.20 & 0.88 & 1.66 & 0.88 & 0.41 & 1.87 & & 1.09 & 0.82 & 1.46 & & 1.12 & 0.91 & 1.37 & 1.48 & 0.94 & 2.32 & \\
\hline I-3 hours/week & 1.11 & 0.85 & 1.45 & 0.91 & 0.50 & 1.66 & & 1.05 & 0.83 & 1.33 & & 1.06 & 0.89 & 1.26 & 1.38 & 0.94 & 2.04 & \\
\hline 4-7 hours/week & 1.00 & 0.77 & 1.31 & 1.04 & 0.59 & 1.86 & & 1.17 & 0.93 & 1.48 & & 1.09 & 0.92 & 1.29 & 1.31 & 0.90 & 1.92 & \\
\hline$>7$ hours/week & 0.99 & 0.77 & 1.27 & 1.04 & 0.59 & 1.86 & 0.99 & 1.14 & 0.91 & 1.42 & 0.00 & 1.06 & 0.90 & 1.25 & 1.15 & 0.79 & 1.66 & 0.91 \\
\hline \multicolumn{19}{|l|}{ Ages 35-39 years } \\
\hline Never/Rarely & $\mathrm{I} .00$ (ref.) & & & 1.00 (ref.) & & & & $\mathrm{I} .00$ (ref.) & & & & 1.00 (ref.) & & & $\mathrm{I} .00$ (ref.) & & & \\
\hline$<$ l hour/week & 1.07 & 0.77 & 1.50 & 1.14 & 0.46 & 2.84 & & 1.21 & 0.90 & 1.65 & & 1.15 & 0.92 & 1.43 & 1.26 & 0.80 & 1.99 & \\
\hline I-3 hours/week & 1.07 & 0.81 & 1.41 & 1.48 & 0.70 & 3.13 & & 1.17 & 0.91 & 1.52 & & 1.15 & 0.95 & 1.38 & 1.17 & 0.80 & 1.73 & \\
\hline 4-7 hours/week & 0.91 & 0.69 & 1.19 & 1.44 & 0.69 & 3.00 & & 1.12 & 0.87 & 1.44 & & 1.04 & 0.87 & 1.25 & 1.07 & 0.73 & 1.57 & \\
\hline$>7$ hours/week & 0.89 & 0.68 & 1.16 & 1.48 & 0.72 & 3.02 & 0.20 & 1.20 & 0.94 & 1.53 & 0.18 & 1.08 & 0.91 & 1.28 & 0.94 & 0.65 & 1.37 & 0.52 \\
\hline \multicolumn{19}{|l|}{ Past 10 years } \\
\hline Never/Rarely & $\mathrm{I} .00$ (ref.) & & & $\mathrm{I} .00$ (ref.) & & & & $\mathrm{I} .00$ (ref.) & & & & 1.00 (ref.) & & & $\mathrm{I} .00$ (ref.) & & & \\
\hline <। hour/week & 1.20 & 0.86 & 1.69 & 0.35 & 0.14 & 0.92 & & 1.24 & 0.94 & 1.64 & & 1.14 & 0.93 & 1.41 & 1.50 & 0.95 & 2.38 & \\
\hline I-3 hours/week & 1.06 & 0.80 & 1.41 & 1.04 & 0.59 & 1.86 & & 1.00 & 0.79 & 1.27 & & 1.03 & 0.86 & 1.22 & 1.35 & 0.91 & 2.02 & \\
\hline 4-7 hours/week & 1.19 & 0.90 & 1.57 & 0.94 & 0.53 & 1.66 & & 1.11 & 0.88 & 1.40 & & 1.12 & 0.95 & 1.33 & 1.24 & 0.83 & 1.84 & \\
\hline$>7$ hours/week & 0.92 & 0.70 & 1.22 & 0.80 & 0.45 & 1.40 & 0.65 & 1.07 & 0.85 & 1.35 & 0.53 & 0.99 & 0.84 & 1.17 & 1.11 & 0.75 & 1.63 & 0.61 \\
\hline No. cancer cases** & 1352 & & & 263 & & & & 1907 & & & & 3522 & & & 736 & & & \\
\hline
\end{tabular}

* Relative risks adjusted for: age (continuous); race/ethnicity (white, black, Hispanic, Asian/Pacific Islander/American Indian); education level (<I2 years or high school equivalent, 12 years or high school equivalent, post-high school vocational or technical training, some college, college graduate, post-graduate); smoking status (non-smoker, former, current); alcohol intake (grams/day, quintiles adjusted for total energy intake); family history of breast cancer (no, yes); age at menarche $(<13,13-14, \geq 15$ years); age at first birth (nulliparous, $<20,20-24,25-29,30+$ years); parity (number of children: $0,1-2,3$ or more); age at menopause ( $<40,40-44,45-49,50-54, \geq 55$ years); menopausal hormone use (never, ever)

** Total numbers of cancer cases may vary due to missing physical activity values.

† ER: estrogen receptor. Hormone rory due to missing physical activity values.

t† p-value for heterogeneity comparing RR for $>7$ hours/week of physical activity: ER-positive and ER-negative tumors.

$\$ p$-value for heterogeneity comparing RR for $>7$ hours/week of physical activity: ER-positive, ER-negative, and ER-unknown tumors.

$\epsilon$ p-value for heterogeneity comparing RR for $>7$ hours/week of physical activity: invasive and in situ tumors 
Table 7: Multivariate adjusted relative risk (RR)* and $95 \%$ confidence intervals $(\mathrm{Cl})$ for the association of light physical activity during four periods of life with breast cancer tumor characteristics: I 18,899 postmenopausal women in the NIH-AARP Diet and Health Study

\begin{tabular}{|c|c|c|c|c|c|c|c|c|c|c|c|c|c|c|c|c|c|c|}
\hline \multirow{2}{*}{$\begin{array}{l}\text { Moderate/ } \\
\text { vigorous activity }\end{array}$} & \multirow[t]{2}{*}{$\begin{array}{l}\text { ER- } \\
\text { positive } \\
\text { tRR }\end{array}$} & \multicolumn{2}{|c|}{$\begin{array}{c}95 \% \\
\mathrm{Cl}\end{array}$} & \multirow{3}{*}{$\begin{array}{c}\begin{array}{c}\text { ER- } \\
\text { negative } \\
\text { RR }\end{array} \\
1.00 \text { (ref.) }\end{array}$} & \multicolumn{2}{|c|}{$\begin{array}{c}95 \% \\
\mathrm{Cl}\end{array}$} & \multirow[t]{2}{*}{$\mathbf{p}^{\dagger \dagger}$} & \multirow[t]{2}{*}{$\begin{array}{c}\text { ER- } \\
\text { unknown } \\
\text { RR }\end{array}$} & \multicolumn{2}{|c|}{$\begin{array}{c}95 \% \\
\mathrm{Cl}\end{array}$} & \multirow[t]{2}{*}{$\mathbf{p}^{\S}$} & \multirow[t]{2}{*}{$\begin{array}{c}\text { Invasive } \\
\text { RR }\end{array}$} & \multicolumn{2}{|c|}{$\begin{array}{c}95 \% \\
\mathrm{Cl}\end{array}$} & \multirow[t]{2}{*}{$\begin{array}{l}\text { In } \\
\text { situ } \\
\text { RR }\end{array}$} & \multicolumn{2}{|c|}{$\begin{array}{c}95 \% \\
\mathrm{Cl}\end{array}$} & \multirow[t]{2}{*}{$\mathbf{p}^{t}$} \\
\hline & & & & & & & & & & & & & & & & & & \\
\hline Never/Rarely & 1.00 (ref.) & & & & & & & 1.00 (ref.) & & & & 1.00 (ref.) & & & 1.00 (ref.) & & & \\
\hline$<$ I hour/week & 1.05 & 0.82 & 1.34 & 0.85 & 0.48 & 1.49 & & 1.08 & 0.89 & 1.31 & & 1.05 & 0.91 & 1.22 & 1.40 & 1.04 & 1.87 & \\
\hline I-3 hours/week & 1.10 & 0.90 & 1.34 & 1.11 & 0.73 & 1.68 & & 0.96 & 0.82 & 1.13 & & 1.02 & 0.91 & 1.15 & 1.20 & 0.93 & 1.53 & \\
\hline 4-7 hours/week & 1.22 & 1.00 & 1.47 & 0.98 & 0.64 & 1.50 & & 0.94 & 0.80 & 1.10 & & 1.04 & 0.93 & 1.17 & 0.90 & 0.70 & 1.17 & \\
\hline$>7$ hours/week & 1.18 & 0.98 & 1.42 & 0.91 & 0.61 & 1.36 & 0.24 & 1.02 & 0.88 & 1.18 & 0.33 & 1.06 & 0.95 & 1.19 & 0.89 & 0.70 & 1.17 & 0.18 \\
\hline \multicolumn{19}{|l|}{ Ages 19-29 years } \\
\hline Never/Rarely & 1.00 (ref.) & & & 1.00 (ref.) & & & & 1.00 (ref.) & & & & 1.00 (ref.) & & & 1.00 (ref.) & & & \\
\hline$<$ l hour/week & 1.18 & 0.92 & 1.52 & 0.99 & 0.56 & 1.76 & & 1.01 & 0.82 & 1.24 & & 1.07 & 0.92 & 1.25 & 1.12 & 0.81 & 1.54 & \\
\hline I-3 hours/week & 1.14 & 0.92 & 1.41 & 0.90 & 0.56 & 1.44 & & 0.99 & 0.84 & 1.18 & & 1.04 & 0.91 & 1.18 & 1.14 & 0.87 & 1.49 & \\
\hline 4-7 hours/week & 1.16 & 0.94 & 1.43 & 1.15 & 0.74 & 1.80 & & 0.94 & 0.79 & 1.11 & & 1.03 & 0.91 & 1.17 & 0.94 & 0.71 & 1.23 & \\
\hline$>7$ hours/week & 1.14 & 0.93 & 1.40 & 0.96 & 0.61 & 1.49 & 0.48 & 0.99 & 0.84 & 1.16 & 0.51 & 1.04 & 0.92 & 1.18 & 0.87 & 0.67 & 1.13 & 0.23 \\
\hline \multicolumn{19}{|l|}{ Ages $35-39$ years } \\
\hline Never/Rarely & 1.00 (ref.) & & & 1.00 (ref.) & & & & 1.00 (ref.) & & & & $\mathrm{I} .00$ (ref.) & & & 1.00 (ref.) & & & \\
\hline$<1$ hour/week & 1.17 & 0.91 & 1.49 & 0.93 & 0.51 & 1.71 & & 1.03 & 0.83 & 1.27 & & 1.07 & 0.92 & 1.25 & 1.23 & 0.90 & 1.68 & \\
\hline I-3 hours/week & 0.99 & 0.80 & 1.23 & 1.25 & 0.77 & 2.02 & & 0.95 & 0.79 & 1.13 & & 0.99 & 0.86 & 1.12 & 0.99 & 0.75 & 1.30 & \\
\hline 4-7 hours/week & 1.08 & 0.88 & 1.33 & 1.14 & 0.71 & 1.84 & & 1.03 & 0.87 & 1.22 & & 1.06 & 0.93 & 1.20 & 0.92 & 0.70 & 1.21 & \\
\hline$>7$ hours/week & 1.01 & 0.82 & 1.24 & 1.01 & 0.63 & 1.63 & 0.99 & 0.99 & 0.83 & 1.17 & 0.99 & 1.00 & 0.88 & 1.13 & 0.85 & 0.65 & 1.12 & 0.31 \\
\hline \multicolumn{19}{|l|}{ Past 10 years } \\
\hline Never/Rarely & 1.00 (ref.) & & & 1.00 (ref.) & & & & 1.00 (ref.) & & & & $\mathrm{I} .00$ (ref.) & & & $\mathrm{I} .00$ (ref.) & & & \\
\hline$<$ l hour/week & 1.18 & 0.97 & 1.45 & 0.60 & 0.35 & 1.03 & & 1.00 & 0.84 & 1.19 & & 1.04 & 0.91 & 1.18 & 1.12 & 0.85 & 1.49 & \\
\hline I-3 hours/week & 0.96 & 0.80 & 1.14 & 0.79 & 0.53 & 1.17 & & 0.88 & 0.76 & 1.01 & & 0.90 & 0.81 & 1.00 & 0.99 & 0.78 & 1.25 & \\
\hline 4-7 hours/week & 0.98 & 0.83 & 1.17 & 0.99 & 0.68 & 1.45 & & 0.87 & 0.75 & 1.01 & & 0.92 & 0.83 & 1.03 & 0.90 & 0.71 & 1.14 & \\
\hline >7 hours/week & 0.77 & 0.64 & 0.92 & 0.87 & 0.58 & 1.29 & 0.58 & 0.89 & 0.77 & 1.03 & 0.56 & 0.84 & 0.75 & 0.94 & 0.85 & 0.66 & 1.08 & 0.96 \\
\hline No. cancer cases** & 1352 & & & 263 & & & & 1907 & & & & 3522 & & & 736 & & & \\
\hline
\end{tabular}

* Relative risks adjusted for: age (continuous); race/ethnicity (white, black, Hispanic, Asian/Pacific Islander/American Indian); education level (<12 years or high school equivalent, 12 years or high school equivalent, post-high school vocational or technical training, some college, college graduate, post-graduate); smoking status (non-smoker, former, current); alcohol intake (grams/day, quintiles adjusted for total energy intake); family history of breast cancer (no, yes); age at menarche $(<13,13-14, \geq 15$ years); age at first birth (nulliparous, $<20,20-24,25-29,30+$ years); parity (number of children: $0,1-2,3$ or more); age at menopause ( $<40,40-44,45-49,50-54, \geq 55$ years); menopausal hormone use (never, ever)

** Total numbers of cancer cases may vary due to missing physical activity values.

† ER: estrogen receptor. Hormone rory due to missing physical activity values.

t† p-value for heterogeneity comparing RR for $>7$ hours/week of physical activity: ER-positive and ER-negative tumors.

$\$ p$-value for heterogeneity comparing RR for $>7$ hours/week of physical activity: ER-positive, ER-negative, and ER-unknown tumors.

$\epsilon$ p-value for heterogeneity comparing RR for $>7$ hours/week of physical activity: invasive and in situ tumors 
Additionally, if participants exhibit better recall of vigorous intensity activities than those of lower intensity [48-50], the observation of an association of moderate-to-vigorous physical activity and the lack of an association of light physical activity with breast cancer risk might be explained not by etiological differences, but by misclassification. Yet in our prospectively designed study, exposure measurement error is likely to be non-differential by case status, whereas misclassification of physical activity level in case-control studies has been shown to distort risk estimates as a result of recall bias [51]. It is possible that we did not observe an association of light intensity physical activity at any time period of life with breast cancer risk due to the examples of light activities given in the questionnaire. Our examples of light intensity activities may have reflected a combination of sedentary behaviors (eg: golf [riding in a cart], fishing) and truly light activities (eg: bowling, table tennis, slow walking/slow dancing, light calisthenics, light gardening, horseshoes/croquet, light housework), thereby preventing the assessment of a true association between breast cancer risk and light physical activity [52]. In addition, while providing categories of physical activity duration $(<1,1-3,4-7$, or $>7$ hours per week) eases the recall burden of participants, such categorization may also permit misclassification if differences in risk exist for more subtle distinctions in the amount of time spent active.

\section{Conclusion}

In summary, our results suggest that moderate-to-vigorous physical activity during later adulthood is associated with reduced postmenopausal breast cancer risk. Future prospective studies designed to assess the relation of physical activity intensity across the lifespan to breast cancer risk will be required to confirm our findings. Although controlled trials or intervention studies are the ideal study designs for disentangling the "dose" of physical activity that may influence breast cancer risk, the cost and duration of such studies for researching the association of physical activity intensity and timing with primary breast cancer limits their feasibility [53]. However, interventions and experimental research will be imperative to investigate the mechanisms by which physical activity intensity and timing influences breast cancer risk.

\section{List of abbreviations}

NIH: National Institutes of Health; AARP: American Association of Retired Persons; ER: estrogen receptor; RR: relative risk; CI: confidence interval; BMI: body mass index; CTS: California Teachers' Study.

\section{Competing interests}

The authors declare that they have no competing interests.

\section{Authors' contributions}

TMP carried out the statistical analysis and drafted the manuscript. TMP, SCM, GLG, NJW, UE, AND MFL partic- ipated in the design and coordination of the study. ARH and AS conceived of the study. All authors read and approved the final manuscript.

\section{Acknowledgements}

This research was supported by the Intramural Research Program of the $\mathrm{NIH}$, National Cancer Institute. Cancer incidence data from the Atlanta metropolitan area were collected by the Georgia Center for Cancer Statistics, Department of Epidemiology, Rollins School of Public Health, Emory University. Cancer incidence data from California were collected by the California Department of Health Services, Cancer Surveillance Section. Cancer incidence data from the Detroit metropolitan area were collected by the Michigan Cancer Surveillance Program, Community Health Administration, State of Michigan. The Florida cancer incidence data used in this report were collected by the Florida Cancer Data System under contract to the Department of Health (DOH). The views expressed herein are solely those of the authors and do not necessarily reflect those of the contractor or $\mathrm{DOH}$. Cancer incidence data from Louisiana were collected by the Louisiana Tumor Registry, Louisiana State University Medical Center in New Orleans. Cancer incidence data from New Jersey were collected by the New Jersey State Cancer Registry, Cancer Epidemiology Services, New Jersey State Department of Health and Senior Services. Cancer incidence data from North Carolina were collected by the North Carolina Central Cancer Registry. Cancer incidence data from Pennsylvania were supplied by the Division of Health Statistics and Research, Pennsylvania Department of Health, Harrisburg, Pennsylvania. The Pennsylvania Department of Health specifically disclaims responsibility for any analyses, interpretations or conclusions.

\section{References}

I. Jemal A, Siegel R, Ward E, Hao Y, Xu J, Murray T, Thun MJ: Cancer statistics, 2008. CA Cancer J Clin 2008, 58:7I-96.

2. Vainio H, Ed: Weight Control and Physical Activity. Lyon, France: IARC Press; 2002.

3. Monninkhof EM, Elias SG, Vlems FA, Tweel I van der, Schuit A], Voskuil DW, van Leeuwen FE: Physical activity and breast cancer: a systematic review. Epidemiology 2007, 18:137-157.

4. WCRF/AICR: Food, Nutrition, Physical Activity and the Prevention of Cancer: a Global Perspectiv. Washington, D.C 2007.

5. Friedenreich CM, Cust AE: Physical activity and breast cancer risk: impact of timing, type and dose of activity and population subgroup effects. BrJ Sports Med 2008, 42:636-647.

6. Leitzmann MF, Moore SC, Peters TM, Lacey JV Jr, Schatzkin A, Schairer C, Brinton LA, Albanes D: Prospective study of physical activity and risk of postmenopausal breast cancer. Breast Cancer Res 2008, 10:R92.

7. Dallal CM, Sullivan-Halley J, Ross RK, Wang Y, Deapen D, Horn-Ross PL, Reynolds P, Stram DO, Clarke CA, Anton-Culver H, Ziogas A, Peel D, West DW, Wright W, Bernstein L: Long-term recreational physical activity and risk of invasive and in situ breast cancer: the California teachers study. Arch Intern Med 2007, 1 67:408-4I5.

8. Tehard B, Friedenreich CM, Oppert JM, Clavel-Chapelon F: Effect of physical activity on women at increased risk of breast cancer: results from the E3N cohort study. Cancer Epidemiol Biomarkers Prev 2006, I 5:57-64.

9. Kruk J: Intensity of lifetime physical activity and breast cancer risk among Polish women. J Sports Sci 2009, 27:437-445.

10. Maruti SS, Willett WC, Feskanich D, Rosner B, Colditz GA: A prospective study of age-specific physical activity and premenopausal breast cancer. J Natl Cancer Inst 2008, I 00:728-737.

II. Lee IM, Rexrode KM, Cook NR, Hennekens CH, Burin JE: Physical activity and breast cancer risk: the Women's Health Study (United States). Cancer Causes Control 200 I, I 2: I37-I45.

12. McTiernan A, Kooperberg C, White E, Wilcox S, Coates R, AdamsCampbell LL, Woods N, Ockene J: Recreational physical activity and the risk of breast cancer in postmenopausal women: the Women's Health Initiative Cohort Study. JAMA 2003, 290: $|33|-\mid 336$. 
13. Friedenreich CM, Courneya KS, Bryant HE: Relation between intensity of physical activity and breast cancer risk reduction. Med Sci Sports Exerc 200 I, 33:1538-1545.

14. Peplonska B, Lissowska J, Hartman T], Szeszenia-Dabrowska N, Blair A, Zatonski W, Sherman ME, Garcia-Closas M, Brinton LA: Adulthood Lifetime Physical Activity and Breast Cancer. Epidemiology 2008, 19:226-236.

15. Slattery ML, Edwards S, Murtaugh MA, Sweeney C, Herrick J, Byers T, Giuliano AR, Baumgartner KB: Physical activity and breast cancer risk among women in the southwestern United States. Ann Epidemiol 2007, 17:342-353.

16. Lagerros YT, Hsieh SF, Hsieh CC: Physical activity in adolescence and young adulthood and breast cancer risk: a quantitative review. Eur J Cancer Prev 2004, 13:5-12.

17. John EM, Horn-Ross PL, Koo J: Lifetime physical activity and breast cancer risk in a multiethnic population: the San Francisco Bay area breast cancer study. Cancer Epidemiol Biomarkers Prev 2003, I2:1|43-1|52.

18. Rockhill B, Willett WC, Hunter DJ, Manson JE, Hankinson SE, Colditz GA: A prospective study of recreational physical activity and breast cancer risk. Arch Intern Med 1999, 159:2290-2296.

19. Dirx MJ, Voorrips LE, Goldbohm RA, Brandt PA van den: Baseline recreational physical activity, history of sports participation, and postmenopausal breast carcinoma risk in the Netherlands Cohort Study. Cancer 200I, 92:1638-1649.

20. Patel AV, Callel EE, Bernstein L, Wu AH, Thun MJ: Recreational physical activity and risk of postmenopausal breast cancer in a large cohort of US women. Cancer Causes Control 2003 1 4:519-529.

21. Neilson HK, Friedenreich CM, Brockton NT, Millikan RC: Physical activity and postmenopausal breast cancer: proposed biologic mechanisms and areas for future research. Cancer Epidemiol Biomarkers Prev 2009, 18: I I-27.

22. McTiernan A: Mechanisms linking physical activity with cancer. Nat Rev Cancer 2008, 8:205-2II.

23. McTiernan A, Wu L, Chen C, Chlebowski R, Mossavar-Rahmani $Y$, Modugno F, Perri MG, Stanczyk FZ, Van Horn L, Wang CY: Relation of BMI and physical activity to sex hormones in postmenopausal women. Obesity (Silver Spring) 2006, 14:1662-1677.

24. Peters TM, Schatzkin A, Gierach GL, Moore SC, Lacey JV Jr, Wareham NJ, Ekelund U, Hollenbeck AR, Leitzmann MF: Physical Activity and Postmenopausal Breast Cancer Risk in the NIHAARP Diet and Health Study. Cancer Epidemiol Biomarkers Prev 2009, 18:289-296.

25. Schatzkin A, Subar AF, Thompson FE, Harlan LC, Tangrea J, Hollenbeck AR, Hurwitz PE, Coyle L, Schussler N, Michaud DS, Freedman LS, Brown CC, Midthune D, Kipnis V: Design and serendipity in establishing a large cohort with wide dietary intake distributions: the National Institutes of Health-American Association of Retired Persons Diet and Health Study. Am J Epidemio 200I, 154:III9-II25.

26. Box GEP, Cox DR: An analysis of transformations. Journal of the Royal Statistical Society 1964, 26:2 II-246.

27. Michaud D: Comparison of cancer registry case ascertainment with SEER estimates and self-reporting in a subset of the NIH-AARP Diet and Health Study. Journal of Registry Management 2005, 32:70-75.

28. Schuit AJ, Schouten EG, Westerterp KR, Saris WH: Validity of the Physical Activity Scale for the Elderly (PASE): according to energy expenditure assessed by the doubly labeled water method. J Clin Epidemiol 1997, 50:54I-546.

29. Washburn RA, Smith KW, Jette AM, Janney CA: The Physical Activity Scale for the Elderly (PASE): development and evaluation. J Clin Epidemiol 1993, 46: I53-162.

30. Cochran $\mathrm{W}$ : The combination of estimates from different experiments. Biometrics 1954, 10:101-129.

31. Haskell WL, Lee IM, Pate RR, Powell KE, Blair SN, Franklin BA, Macera CA, Heath GW, Thompson PD, Bauman A: Physical activity and public health: updated recommendation for adults from the American College of Sports Medicine and the American Heart Association. Med Sci Sports Exerc 2007, 39: I423-I434.

32. Physical Activity Guidelines Advisory Committee, U.S. Department of Health and Human Services: Physical Activity Guidelines Advisory Committee Report, 2008. Washington, D.C 2008.
33. Jasienska G, Ziomkiewicz A, Thune I, Lipson SF, Ellison PT: Habitual physical activity and estradiol levels in women of reproductive age. Eur J Cancer Prev 2006, 1 5:439-445.

34. DiPietro L, Dziura J, Yeckel CW, Neufer PD: Exercise and improved insulin sensitivity in older women: evidence of the enduring benefits of higher intensity training. J Appl Physiol 2006, 100: : 42-149.

35. McTiernan A, Tworoger SS, Ulrich CM, Yasui Y, Irwin ML, Rajan KB, Sorensen B, Rudolph RE, Bowen D, Stanczyk FZ, Potter JD, Schwartz RS: Effect of exercise on serum estrogens in postmenopausal women: a 12-month randomized clinical trial. Cancer Res 2004, 64:2923-2928.

36. Atkinson C, Lampe JW, Tworoger SS, Ulrich CM, Bowen D, Irwin ML, Schwartz RS, Rajan BK, Yasui Y, Potter JD, McTiernan A: Effects of a moderate intensity exercise intervention on estrogen metabolism in postmenopausal women. Cancer Epidemiol Biomarkers Prev 2004, 13:868-874.

37. Gleeson M: Immune function in sport and exercise. J Appl Physiol 2007, 103:693-699.

38. Bernstein L, Patel AV, Ursin G, Sullivan-Halley J, Press MF, Deapen D, Berlin JA, Daling JR, McDonald JA, Norman SA, Malone KE, Strom BL, Liff J, Folger SG, Simon MS, Burkman RT, Marchbanks PA, Weiss LK, Spirtas R: Lifetime recreational exercise activity and breast cancer risk among black women and white women. J Nat/ Cancer Inst 2005, 97:167|-1679.

39. Enger SM, Ross RK, Paganini-Hill A, Carpenter CL, Bernstein L: Body size, physical activity, and breast cancer hormone receptor status: results from two case-control studies. Cancer Epidemio Biomarkers Prev 2000, 9:68I-687.

40. Adams SA, Matthews CE, Hebert JR, Moore CG, Cunningham JE, Shu XO, Fulton J, Gao Y, Zheng W: Association of physical activity with hormone receptor status: the Shanghai Breast Cancer Study. Cancer Epidemiol Biomarkers Prev 2006, I 5: I I 70-I I 78.

4I. Schmidt ME, Steindorf K, Mutschelknauss E, Slanger T, Kropp S, Obi $\mathrm{N}$, Flesch-Janys D, Chang-Claude J: Physical activity and postmenopausal breast cancer: effect modification by breast cancer subtypes and effective periods in life. Cancer Epidemiol Biomarkers Prev 2008, 17:3402-3410.

42. Bardia A, Hartmann LC, Vachon CM, Vierkant RA, Wang AH, Olson JE, Sellers TA, Cerhan JR: Recreational physical activity and risk of postmenopausal breast cancer based on hormone receptor status. Arch Intern Med 2006, 166:2478-2483.

43. Bernstein L, Henderson BE, Hanisch R, Sullivan-Halley J, Ross RK: Physical exercise and reduced risk of breast cancer in young women. I Natl Cancer Inst I994, 86: I 403-I 408

44. Gammon MD, Schoenberg JB, Britton JA, Kelsey JL, Coates RJ, Brogan D, Potischman N, Swanson CA, Daling JR, Stanford JL, Brinton LA: Recreational physical activity and breast cancer risk among women under age 45 years. Am J Epidemiol 1998, 147:273-280.

45. Behavioral Risk Factor Surveillance System Survey Data, Centers for Disease Control and Prevention (CDC). Behavioral Risk Factor Surveillance System Survey Data 2007 [http://apps.nccd.cdc.gov/brfss]. Atlanta, Georgia: U.S. Department of Health and Human Services, Centers for Disease Control and Prevention

46. DuBose KD, Edwards S, Ainsworth BE, Reis JP, Slattery ML: Validation of a historical physical activity questionnaire in middleaged women. J Phys Act Health 2007, 4:343-355.

47. Winters-Hart CS, Brach JS, Storti KL, Trauth JM, Kriska AM: Validity of a questionnaire to assess historical physical activity in older women. Med Sci Sports Exerc 2004, 36:2082-2087.

48. Blair SN, Dowda M, Pate RR, Kronenfeld J, Howe HG Jr, Parker G, Blair A, Fridinger F: Reliability of long-term recall of participation in physical activity by middle-aged men and women. Am J Epidemiol 1991, | 33:266-275.

49. Slattery ML, Jacobs DR Jr: Assessment of ability to recall physical activity of several years ago. Ann Epidemiol 1995, 5:292-296.

50. Friedenreich CM, Courneya KS, Bryant HE: The lifetime total physical activity questionnaire: development and reliability. Med Sci Sports Exerc 1998, 30:266-274.

51. Maruti SS, Willett WC, Feskanich D, Levine B, Rosner B, Colditz GA: Physical activity and premenopausal breast cancer: an examination of recall and selection bias. Cancer Causes Control 2008 20:549-558.

52. Hamilton MT, Healy GN, Dunstan DW, Zderic TW, Owen N: Too Little Exercise and Too Much Sitting: Inactivity Physiology 
and the Need for New Recommendations on Sedentary Behavior. Current Cardiovascular Risk Reports 2008, 2:292-298.

53. Ballard-Barbash R, Hunsberger S, Alciati MH, Blair SN, Goodwin PJ, McTiernan A, Wing R, Schatzkin A: Physical activity, weight control, and breast cancer risk and survival: clinical trial rationale and design considerations. J Natl Cancer Inst 2009, 101:630-643.

\section{Pre-publication history}

The pre-publication history for this paper can be accessed here:

http://www.biomedcentral.com/1471-2407/9/349/pre pub

Publish with Bio Med Central and every scientist can read your work free of charge

"BioMed Central will be the most significant development for disseminating the results of biomedical research in our lifetime. " Sir Paul Nurse, Cancer Research UK

Your research papers will be:

- available free of charge to the entire biomedical community

- peer reviewed and published immediately upon acceptance

- cited in PubMed and archived on PubMed Central

- yours - you keep the copyright

Submit your manuscript here:

http://www.biomedcentral.com/info/publishing_adv.asp 